\title{
Looking inside the spiky bits: a critical review and conceptualisation of entrepreneurial ecosystems
}

\author{
Ross Brown • Colin Mason
}

Accepted: 14 March 2017 / Published online: 2 May 2017

(C) The Author(s) 2017. This article is an open access publication

\begin{abstract}
The concept of entrepreneurial ecosystems has quickly established itself as one of the latest 'fads' in entrepreneurship research. At face value, this kind of systemic approach to entrepreneurship offers a new and distinctive path for scholars and policy makers to help understand and foster growth-oriented entrepreneurship. However, its lack of specification and conceptual limitations has undoubtedly hindered our understanding of these complex organisms. Indeed, the rapid adoption of the concept has tended to overlook the heterogeneous nature of ecosystems. This paper provides a critical review and conceptualisation of the ecosystems concept: it unpacks the dynamics of the concept; outlines its theoretical limitations; measurement approaches and use in policy-making. It sets out a preliminary taxonomy of different archetypal ecosystems. The paper concludes that entrepreneurial ecosystems are a highly variegated, multi-actor and multi-scalar phenomenon, requiring bespoke policy interventions.
\end{abstract}

Keywords Entrepreneurship · High growth · Entrepreneurial ecosystems $\cdot$ Entrepreneurship policy

R. Brown $(\bowtie)$

Centre for Responsible Banking and Finance, School of Management, University of St Andrews, St Andrews, UK e-mail: Ross.Brown@st-andrews.ac.uk

C. Mason

Adam Smith School of Business, University of Glasgow, Glasgow, UK

e-mail: Colin.Mason@glasgow.ac.uk
JEL Classification L26 $\mathrm{L} 53 \cdot \mathrm{O} 25 \cdot \mathrm{R} 11 \cdot \mathrm{R} 58$

\section{Introduction}

The spatial concentration of economic activity is one of the most enduring traits of contemporary capitalism (Marshall, 1890; Myrdal, 1957; Krugman, 1991; Fujita et al., 2001; Scott, 2006). Rather than a world of equal opportunity where globalisation and telecommunications eradicate the importance of geographical distance - the so-called 'flat world' thesis (Friedman, 2007) - the contours of the world economy appear inherently and, enduringly, 'spiky' (Florida, 2005). Arguably, technological advancement has accentuated this process making the world 'more curved' than ever before (McCann, 2008, p. 368; Rodríguez-Pose and Crescenzi, 2008).

As a consequence of these powerful centripetal forces, entrepreneurs are drawn to and, inextricably bound together, with other core entrepreneurial actors in close geographic, institutional and relational proximity. In recent years, entrepreneurial ecosystems (EEs) has become the latest conceptual 'fad' (Martin, 2015) seeking to help explain the dynamics of these entrepreneurial 'spiky bits' (Neck et al., 2004; Isenberg, 2011; Mason and Brown, 2014; WEF, 2014; Stam, 2015). While this systemic concept is intuitively appealing, its rapid adoption has tended to overlook the heterogeneous nature of specific ecosystems. Given the increasing attention being paid to the concept by scholars (Mason and Brown, 2014; Audretsch and Belitski, 2016) 
together with its increasing prominence in public policy circles (Isenberg and Onyemah, 2016), it appears timely to scrutinise the concept in greater depth to help develop this important area of research (Borissenko and Boschma, 2016).

Accordingly, this paper offers a critical review and conceptualisation of the ecosystems concept by unpacking its theoretical limitations, core dynamics, measurement approaches and use in policy-making. In doing so, it aims to provide a way forward for scholars and, potentially, help policy makers apply the concept more fruitfully. To highlight their heterogeneous and path dependent nature, a preliminary taxonomy of archetypal ecosystems is proposed. The paper concludes that entrepreneurial ecosystems are highly variegated, multi-actor and multi-scalar phenomenon which therefore requires bespoke policy interventions. The remainder of the paper is as follows. First, it provides a review of the literature then assesses the definitional ambiguities surrounding the concept. It then delineates the main components of EEs. It then critiques how scholars have assessed, measured and conceptualised the concept as well as proposing a classification of EEs. In the penultimate section, policy implications are explored before conclusions are offered.

\section{Literature review}

Analysing the process of spatial agglomeration has been a source of great fascination for scholars during the last century and more. This began with Marshall's (1890) pioneering analysis of the industrial concentrations in Victorian England which led to the identification of 'agglomeration economies'. Firms accrue multiple pecuniary and non-pecuniary advantages firms from spatial co-location with firms in the same sector, notably the development of specialised pools of human capital, the creation of specialist suppliers and the creation of specialist infrastructure benefiting firms in the same sector (Marshall, 1890). These Marshallian externalities contrast with so-called Jacobian externalities (Jacobs, 1969). Jacobs argued that knowledge may spillover between unrelated industries within urbanised agglomerations as 'ideas developed by one industry can be applied in other industries' (van der Panne, 2004, p. 595). However, the literature is largely inconclusive over whether
Marshallian specialisation or Jacobian diversification externalities most favours regional innovation (van der Panne and Van Beers, 2006).

Marshall's work attracted little attention for much of the twentieth century when neo-classical economics dominated. However, interest in geographical foundations of industrial success re-awakened during the 1980s and 1990s when the 'new economic geography' took centre-stage (Feldman and Tavassoli, 2015). While some scholars question the true novelty of these perspectives (Martin, 1999), instrumental to this trend was the large number of investigations on the evolutionary dynamics of the so-called 'Third Italy' - the dense networks of inter-related SMEs based around traditional industrial sectors such as ceramics, machine tools and textiles based in northern Italy (Piore and Sabel, 1984; Harrison, 1992). In the 1990s, research shifted to geographical 'clusters' (Porter, 2000; Martin and Sunley, 2003). In these locations, firms were thought to benefit from the local sectoral specialisation and knowledge spillovers (i.e. both Marshallian and Jacobian externalities). Socially embedded 'untraded interdependencies' (external to the firm but internal to a region) provided firms with access to human capital, knowledge exchange and specialist suppliers (Scott, 1988; Storper, 1995). However, this phenomenon is highly variegated (Markusen, 1996). Adopting a similar neo-Marshallian perspective, Saxenian's (1996) groundbreaking study contrasted the nature of Route 128 and Silicon Valley to show that different clusters operate in fundamentally different ways. Although both are highly successful regions, their internal dynamics and workings were deemed fundamentally different and distinctive (Saxenian, 1996).

Despite this long lineage of work, it has been Michael Porter whose name has become inextricably linked to the cluster concept. As well as stimulating a vast literature examining clusters his work had the important role of translating the concept for policy makers who then produced a panoply of cluster policies that were adopted around the world (Martin and Sunley, 2003). This, in turn, propelled the cluster concept even higher up the agenda for policy makers (Hospers, 2006) and the quest to generate the next Silicon Valley become something of the 'holy grail' for regional policy makers intent on 'replication' (Neck et al., 2004; Isenberg, 2011; Feldman, 2014). Indeed, it is hard to overstate the prevalence of 'cluster policy' which became the 'principal tool deployed by places to generate a strong and 
sustained economic performance' (Audretsch, 2015, p. 7).

In parallel with the growth of the cluster literature, innovation scholars devised the concept of innovation systems to understand the systemic processes underpinning localised knowledge generation and transfer (Freeman, 1995; Lundvall, 2010). A key focus of this concept is its emphasis on the relational aspects between different institutional actors and how this facilitates the innovation process. Economic geographers were quick to see the attractiveness of this approach to examine the regional construction of the knowledge architecture in many economies by initiating the concept of regional innovation systems (or RIS) (Cooke et al., 1997; Asheim et al., 2011). Key actors within a RIS are universities, research organisations, technical training colleges, regulatory bodies and venture capitalists. These actors are thought to play a key role in orchestrating the innovation process within regional economies (Cooke et al., 1997). The novel feature of this work was the emphasis it placed on the wide array of institutional actors which play a role in the construction and dissemination of knowledge.

On a micro-level, the related concept of technological 'competence blocs' was introduced by scholars to denote the role different institutional actors play in aiding the transformation of knowledge into commercial products in science based contexts in and around university campuses and science parks (Eliasson, 2000). Competence blocs are the defined as the infrastructure necessary to create, select and diffuse new ideas throughout clusters of firms (Eliasson and Eliasson, 1996). Eliasson viewed these institutional factors as crucial for aiding Marshallian externalities. These systemic approaches to innovation have had a powerful impact in shaping industrial policy across many OECD economies (Carlsson et al., 2002; Warwick, 2013).

Following in the wake of these concepts, EEs is the latest conceptual tool designed to shed light on these centripetal agglomerative forces. In contrast to the innovation systems literature where institutions play an overarching role, within the EE construct entrepreneurs are the central actors. The EE literature 'aims to explain (ambitious) entrepreneurship' from a systemic perspective (Borrissenko and Boschma, 2016, p. 14). While entrepreneurial agency is at the core of this concept, it cannot be viewed in isolation given that 'entrepreneurship takes place in a community of interdependent actors' (Stam, 2015, p. 1761). This implies that the construction of successful entrepreneurial regions is not simply a function of firm-specific attributes, but is mediated by the wider context within which ventures operate (Mason and Brown, 2014). Emphasising the relational and institutional foundations (and synergies) of economic success within localised contexts suggests that the dynamic interactions between actors produces more than the 'sum of their parts'. Unsurprisingly, much of the work on EEs strongly corresponds with the systemic literature on innovation systems outlined above (Borissenko and Boschma, 2016), especially the focus on the relational elements between multi-actor networks within regions which govern entrepreneurship and knowledge creation.

The theoretical concept of EEs has been informed by a variety of different literatures. Various scholars have attempted to explore and interpret ecosystems with respect to their social, cultural, behavioural, institutional and biological determinants. Indeed, the fusion of these diverse perspectives is perhaps its strongest asset but at the same time makes definitional and measurement issues extremely problematic (Audretsch and Belitski, 2016). While scholars have traditionally viewed the process of new firm formation through a resourcebased lens (Garnsey, 1998), more recently greater attention has been attributed to the behavioural, social and cultural underpinnings of entrepreneurship (Sarasvathy, 2001; Baker and Nelson, 2005; Welter, 2011). The primary outcome from this wider research focus has been a much stronger focus on the 'localised' determinants of entrepreneurship (Acs et al., 2014; Autio et al., 2014). Arguably, this stronger focus on the multiple relational and spatially embedded processes which coalesce to shape entrepreneurial ecosystems amounts to something of a 'spatial turn' within entrepreneurship. Indeed, it is combination of distinctive localised characteristics - be they social, institutional and relationalwithin ecosystems which lend the concept its explanatory power.

The EE concept therefore offers a potentially new and insightful theoretical framework for analysing the underlying dynamics of how new venture formation occurs and is more plentiful and growth-oriented in certain geographical locations than others. But while conceptually and intuitively appealing, the literature lacks a common understanding of what EEs are and has not been subjected to sufficient rigorous theoretical and empirical scrutiny (Stam, 2015). Furthermore, some early work adopted a normative approach speculating 
how to 'create' ecosystems (Cohen, 2006). While attractive to policy makers, this lack of specificity increases the likelihood of misapplication. Like clusters, how ecosystems become established and evolve is varied (Martin and Sunley, 2011). Specifically, there is 'little understanding' of how successful ones come into existence (Feldman and Braunerhjelm, 2006, p. 1). EEs are heavily path dependent and rooted in their historical and institutional trajectory (Nelson and Winter, 1982; Feldman and Braunerhjelm, 2006). Consequently, every ecosystem is unique with its own distinctive idiosyncrasies and characteristics which are spatially, relationally and socially embedded.

\section{Defining entrepreneurial ecosystems}

EEs have been subject to a large degree of interpretative flexibility, which is largely a function of their diverse intellectual antecedents. The biological metaphor was first coined by James Moore (1993) when he stated 'business ecosystems condense out of the original swirl of capital, customer interest, and talent generated by a new innovation, just as successful species spring from the natural resources of sunlight, water, and soil nutrients' (Moore, 1993 p. 76). This link to biological ecosystems denotes the complex interactions and interdependencies which shape EEs. Drawing on work undertaken on biological ecosystems these evolving organisms can be viewed as 'prototypical examples of complex adaptive systems' where ecosystem properties constantly change and evolve, often in non-linear ways (Levin, 1998, p. 431). As Moore states 'innovative businesses can't evolve in a vacuum' (p. 75). While originally introduced by Moore (1993), it has been the US entrepreneurship academic Daniel Isenberg who popularised the concept, particularly amongst nonacademic audiences (Isenberg, 2010, 2011). Indeed, while the concept can claim multiple ancestries (Mason and Brown, 2014), its origins are in the 'grey' business literature and practitioner communities (Isenberg, 2010; Napier and Hansen, 2011; Feld, 2012). Accordingly, it offers a practical perspective rather than a purely theoretical one (Kantis and Frederico, 2012; Isenberg, 2011; Napier and Hansen, 2011).

There is no uniform or commonly accepted definition of EEs however various attempts have been made recently to define the concept. Typically, definitions convey the importance of localised and interdependent relationships between different entrepreneurial actors as key ingredients driving the performance of EEs. Stam (2015) offers a broad definition of EEs as a 'set of interdependent actors and factors coordinated in such a way that they enable productive entrepreneurship' ( $p$. 1765). Mason and Brown (2014, p. 5) set out a more comprehensive definition of EEs as a 'set of interconnected entrepreneurial actors, entrepreneurial organizations, institutions and entrepreneurial processes which formally and informally coalesce to connect, mediate and govern the performance within the local entrepreneurial environment'. Clearly, the dynamic and systemic nature of the concept encompasses multiple actors, institutions and processes.

The concept has been used differently within the literature making it a rather 'chaotic' (Martin and Sunley, 2003) or 'fuzzy' concept (Markusen, 1999). According to some, they represent 'a conceptual umbrella encompassing a variety of different perspectives on the geography of entrepreneurship rather than a coherent theory' (Spigel, 2015, p. 1). Part of this confusion stems from the fact that the term has been applied in both geographical and non-geographical contexts. As Moore (1993) did himself, some view ecosystems as a facilitator of innovation where different actors interact and work to help cumulatively co-produce new knowledge (Malecki, 2011; Zahra and Nambisan, 2011). The example of Google's Android innovation ecosystem is often held up as an exemplar of this phenomenon (Nambisan and Baron, 2013). This approach has considerable value and has been shown to reveal powerful insights how a population of technologically differentiated firms 'mutually and iteratively discover, create and enact innovation opportunities' (Best, 2015, p. 12).

However, the majority of observers view ecosystems primarily as a spatial concept (Feldman and Braunerhjelm, 2006; Mason and Brown, 2014; Audretsch and Belitski, 2016) to explain why certain places have high levels of entrepreneurial activity (Spigel, 2015; Stam, 2015). So rather than having innovation at its core, entrepreneurship is the fundamental driver behind the concept. In this paper we view EEs through this lens.

One aspect of EEs often overlooked in the emerging literature is the fundamental role played by social and cultural factors in shaping entrepreneurship (Venkataraman, 2004). In many respects, entrepreneurship takes place within the framework of 'sociocultural 
structures' (Spilling, 1996, p. 92) which are fundamentally determined locally and are heavily path-dependent (Gertler, 2010; Welter, 2011). A good example of the deeply embedded nature of entrepreneurship is the world-renowned German Mittelstand companies with their close connections to regionalised banks, schools, local government and research centres (De Massis et al., 2017). Other scholars have shown how the experience of Israeli entrepreneurs has been heavily shaped by military experience where non-hierarchical structures encourage problem-solving and innovative thinking (Senor and Singer, 2009). In other words, social and organisational ties are deeply 'intertwined' (Ferrary and Granovetter, 2009).

Another issue that has been overlooked concerns the temporally unfolding and evolutionary nature of EEs (Borissenko and Boschma, 2016). A key feature of ecosystems is nonlinearity. Significant changes can occur within ecosystems over time, not least due to changes in government policy, resulting in multiple possible outcomes in their developmental trajectories. This kind of evolutionary thinking has shaped the way in which scholars conceptualise the evolution of clusters (Martin and Sunley, 2011). Given their similarities, such an approach may be an equally fruitful mechanism for understanding EEs.

In summary, the initial conceptualisations of EEs appear to be somewhat under-socialised, lacking a time dimension and fail to incorporate the full complexities of the socio-spatial context mediating entrepreneurship. These omissions are evident in the mechanistic forms of measurement which have been utilised to assess ecosystems. This myopic focus is common within the entrepreneurship literature as a whole which is preoccupied with characteristics and behaviours of individuals and firms (Borissenko and Boschma, 2016), whilst often ignoring how the context of firms regulates their 'behaviour, choices, and performance' (Autio et al., 2014, p. 1099).

\section{Entrepreneurial ecosystems: taking a look inside}

The concept of ecosystems is an inherently dynamic one which acknowledges the importance of entrepreneurial processes and cognitive belief systems which underpin interactions within an economy. Just as there is an evolutionary logic to cluster formation (Feldman and Braunerhjelm, 2006), some observers note that ecosystems are 'a naturally evolving system' (Isenberg, 2010). Figure 1 presents the diverse types of actors within EEs.

In contrast to some practitioner viewpoints (Feld, 2012), a myth we wish to refute is that ecosystems are predominantly about start-ups. According to some, this focus is symptomatic of the misplaced obsession with SMEs and start-ups in terms of their ability to generate innovation and growth (Isenberg, 2012; Fritsch and Storey, 2014; Mazzucato 2014), despite significant evidence to the contrary (Nightingale and Coad, 2014; Shane, 2009). As Vivarelli (2004, p. 48) notes 'the conventional wisdom is that start-ups are good per se and that all the potential entrepreneurs have to be helped'. However, research in both advanced and developing countries (Vivarelli, 2004; Vivarelli, 2013; Quatraro and Vivarelli, 2015) shows that this tends to encourage low-quality entrants and associated deadweight (Shane, 2009). This owes to the underlying causal drivers of entrepreneurship which often fosters so-called 'necessity entrepreneurs' (Baumol, 1996) pushed into entrepreneurship by 'regressive' drivers such as fear of unemployment (Vivarelli, 2013). Growth-oriented opportunity entrepreneurs on the other hand have a very different entrepreneurial and behavioural make up (Baumol, 1996; Amit et al., 2001).

The crucial aspect of ecosystems are the actors, processes and institutions which are not directly related to start-ups, such as large firms, universities, public sector bodies, health care systems, banks and stock markets (Isenberg 2010; Mason and Brown, 2014). Entrepreneurial universities, in particular, are widely seen as a vital entrepreneurial actors (Guerrero et al., 2016) while others take the view that their role has been over-stated (Brown, 2016). The role of large existing firms, in contrast, is often downplayed with the EE literature. However, there is considerable evidence which shows that large incumbent firms often play a central role in configuring some ecosystems (Mayer, 2013), as attractors of skilled labour (Harrison et al., 2004); the incubation of entrepreneurs, the spill-over of knowledge and as important initial customers (Eliasson, 2000). In some areas, large exogenous defence companies play a central role in shaping EEs (Adams, 2011). These roles are pivotal in configuring the nature of a local entrepreneurial context but tend to be overlooked in some of the EE literature (WEF, 2014; Spigel, 2015).

One thing ecosystems do have in common is a spatial boundedness. Close geographic proximity fosters 
Fig. 1 A basic graphical representation of an entrepreneurial ecosystem. Adapted from Isenberg (2011)

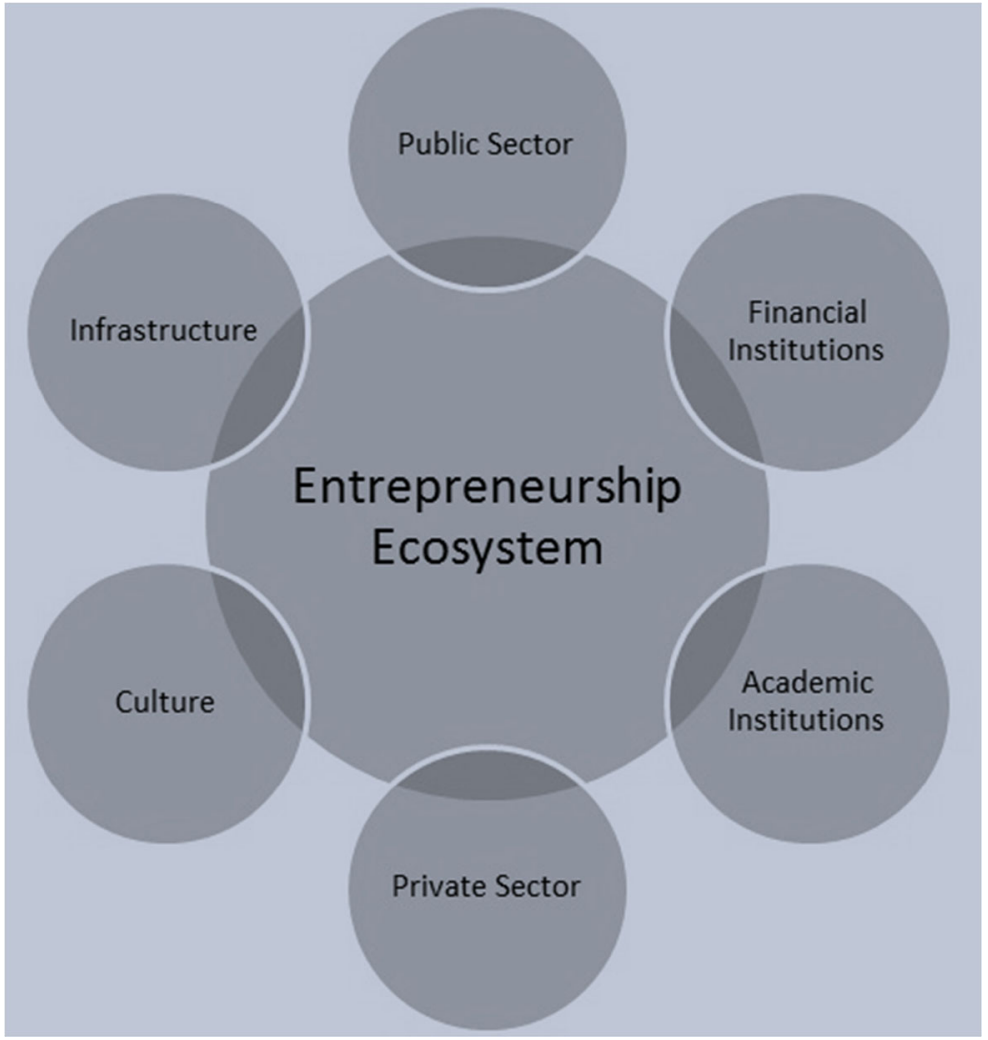

network formation and knowledge exchange and most ecosystems follow a strong spatial logic (Glückler, 2007). While some are focused around large urban conurbations, others operate at a regional level or in some rare case at the national level (e.g. Estonia). In some cases, EEs are characterised by more complex 'nested geographies' (i.e. EEs located within larger EEs) which involves multi-scaler interactions with other entrepreneurial actors on a number of different spatial levels, both domestically and internationally. So while the role of local institutions matters, so too does the 'connectivity between those elements' (Motoyama and Knowlton, 2016, p. 20). This is particularly important for enabling learning processes which are 'intrinsically social and collective phenomena....involving joint contributions to the understanding of complex problems' (Teece, et al., 1994, p. 15). This echoes other work which emphasises how networking and relational factors are crucial for early stage ventures more generally (Sullivan \& Ford, 2014; Witt, 2004).

In order to delineate the main actors, interactions and cognitive mind-sets within these complex systems, we propose a taxonomy featuring four main coordinative aspects of EEs which we will consider in turn: entrepreneurial actors; entrepreneurial resource providers; entrepreneurial connectors and entrepreneurial culture (see Fig. 2 below).

\subsection{Entrepreneurial actors}

It is commonly agreed that entrepreneurship and entrepreneurial actors are at the heart of the ecosystem concept (Isenberg, 2010; Mason and Brown, 2014; Stam, 2015). Whereas the systemic innovation literature portrays entrepreneurship as something of a 'black box' (Stam, 2015), entrepreneurs and supporting entrepreneurial infrastructure are the core actors within this analytical concept. This is very much in line with those who wish to adopt a systemic approach towards understanding entrepreneurship more generally through the concept of national systems of entrepreneurship (Acs et al., 2014). This approach differs from the innovation systems approach in that individuals in pursuit of new venture creation and growth are at the heart of the concept. However, while this focus on the entrepreneur is a welcome progression to the systemic literature, it 


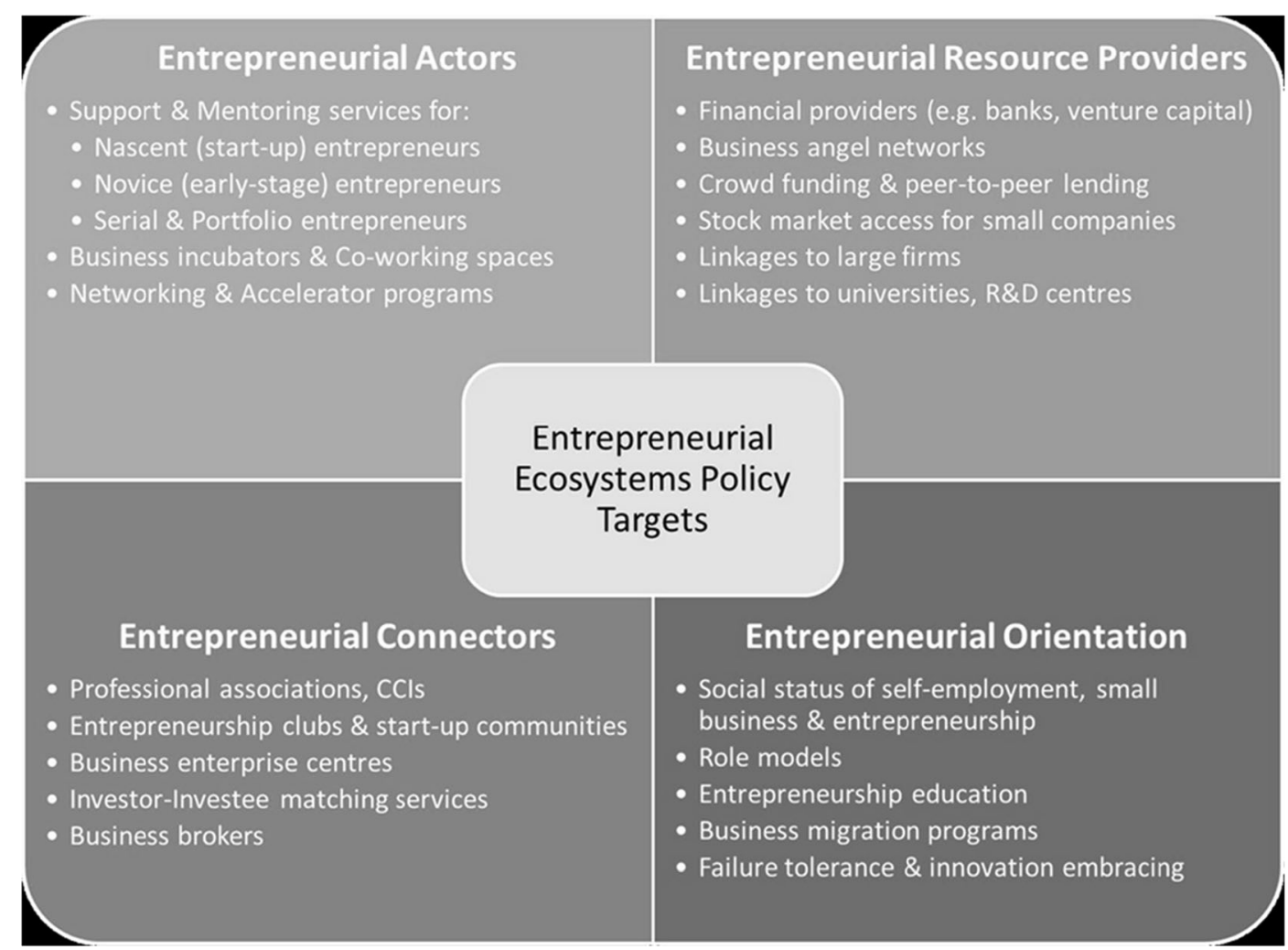

Fig. 2 Key actors and inter-relationships within entrepreneurial ecosystems.

Source: Mason and Brown (2014)

fails to properly address the spatial specificities of entrepreneurship.

Just as economic geographers were quick to critique the 'national' systems of innovation approach (Cooke et al., 1997), numerous scholars have noted that entrepreneurship is fundamentally a localised phenomenon (Stam, 2007; Dahl and Sorenson, 2009; Feldman et al., 2005; Feldman, 2014; Gertler, 2010; Welter 2011). The regional systems of entrepreneurship approach acknowledges how regional factors 'interactively influence the creation, discovery and exploitation of entrepreneurial opportunities' (Qian et al., 2013, p. 560). Indeed, one of the benefits of the EE perspective is that it recognises that the entrepreneurship is fundamentally mediated within a local context (Mason and Brown, 2014; Spigel, 2015). That said, recognition also needs to be taken into account of the role of nonlocal interactions between entrepreneurs and nonlocal parties. A good example would be the crucial role of transnational entrepreneurship and external $\mathrm{VC}$ have played in developing some ecosystems
(Mason et al., 2002: Saxenian, 2006; Drori et al., 2009; Lerner, 2010). The fundamental importance of these 'global pipelines' has been recognised in the literature on clusters (Bathelt et al., 2004). Researchers need to be cognisant of the important role these multi-scaler interactions have for local EEs.

While scholars have highlighted the pivotal role entrepreneurs play within dynamic local ecosystems, much less attention is given to the antecedents of these initial processes. While considerable research shows that clusters of related activity facilitate the creation of start-ups (Delgado et al., 2010), these studies fail to explain why the cluster arose in the first place (Feldman and Braunerhjelm, 2006). Thorny 'chicken and egg' questions are ignored (Mason and Brown, 2014). Part of this stems from a lack of focus on key individuals within the emergence of clusters (Feldman, 2014). Yet key individuals have been shown to play a critical role in the creation of a vibrant local economies (Feldman et al., 2005). A well-cited example is the role of the entrepreneur, Herman Hauser, best known as 
one of the founders of Acorn Computer and subsequent founder of Amadeus, a VC firm, who played a key role in the development of Cambridge as a hightech region (Garnsey and Heffernen, 2005).

\subsubsection{Entrepreneurial re-cycling}

The relational factors mediating entrepreneurship are something which defines most ecosystems. Interactions between entrepreneurs not only act as a source of inspiration and role models for the next generation of entrepreneurs but they can also directly help to nurture or mentor new entrepreneurs through their own pro-social behaviour and formal mentoring. Entrepreneurship therefore has a 'cumulative' self-perpetuating effect on future levels of entrepreneurship.

Not only that, but a process known as 'entrepreneurial re-cycling' takes place in economies which can act as an important catalyst for further entrepreneurial activity (Mason and Harrison, 2006). Both cashed-out entrepreneurs who have sold-off their business and those who are no longer involved in the day-to-day operations often seek to re-invest their 'harvest' into other promising new ventures as 'business angels', investing in new and young businesses and providing hands-on support. This process also tends to be local. For example, most business angels tend to favour investment in investee businesses that are in close geographic proximity (Harrison et al., 2010). The net result of this process means that past successes can generate critical injections of investment back into the local economy. The bigger the financial harvest the more opportunity there is for large-scale re-investment in the local EE. Therefore, success breeds success through this process of cumulative entrepreneurship.

The process of entrepreneurial re-cycling also involves the transfer of entrepreneurial learning within ecosystems. This may involve some individuals becoming serial entrepreneurs, 'dealmakers' (see section 3.3 below), business advisors, mentors and non-executive directors. Serial entrepreneurs in particular play a pivotal role within economies as venturing tends to confer positive spillovers from one venture into subsequent ones even when their initial ventures perform poorly (Parker, 2013). Zhang's (2011) study of entrepreneurs in Silicon Valley showed that serial entrepreneurs also raise higher levels of VC than de novo entrepreneurs.

\subsubsection{Blockbuster entrepreneurship}

The role of so-called 'blockbuster entrepreneurship' (Napier and Hansen, 2011) is also critical in the development of EEs (Mason and Brown, 2014). Also labelled 'breakout companies' (WEF, 2014 p. 4), these are 'young successful entrepreneurial firms that have grown exceptionally in size and wealth' (Napier and Hansen, 2011 p.3). Isenberg (2010) stresses his 'law of small numbers' which states that only a handful of entrepreneurial successes are needed to have major benefits for the ecosystem in terms of spillover effects such as role models, serial entrepreneurs, angel investors, venture capitalists, board members, advisors and mentors. This is confirmed in various clusters (Feldman and Braunerhjelm, 2006).

Entrepreneurship scholars and policy makers have recently become fascinated with the role of high growth firms (HGFs) (Henrekson and Johansson, 2010; Brown et al., 2017), young innovative companies (YICs) (Schneider and Veugelers 2010) and new technology based firms (NTBFs) (Colombo and Grilli, 2007). Most of whom are typically small. By contrast, they have tended to overlook the crucial role played by larger scale corporate successes within economies. However, in recognition of the systemic role large organisations play in EEs, the nascent ecosystems literature highlights the importance and spillovers of firms that scale-up to become the future blockbusters (Napier and Hansen, 2011; Coutu, 2014; Isenberg and Brown, 2014). Even blockbusters that subsequently 'flop' can bring positive externalities for regions in terms of spin-offs (see Buenstorf and Fornahl, 2009). ${ }^{1}$

This distinction between HGFs and scaled-up firms is very important because, for a variety of reasons, most HGFs do not upscale into larger corporate entities. Many are in fact 'one hit wonders' (Daunfeldt and Halversson, 2015). Many HGFs cease growing, some will close and others will become acquired (Lee et al., 2016). Barriers accessing finance is often a key growth constraint for these rapidly growing innovative firms (Colombo and Grilli, 2007; Schneider and Veugelers 2010; Lee, 2014). Only a handful of 'abnormal' firms can sustain continuous rapid growth enabling them to transform into larger scale corporate entities or so-called

\footnotetext{
${ }^{1}$ For example, many of the entrepreneurs and employees within the Finnish computer games companies such as Rovio and Supercell are direct descendants of Nokia.
} 
companies of scale. While there is no precise definition of companies of scale, policy makers in the UK claim such firms have a turnover between $£ 10-100 \mathrm{~m}$ (Brown and Mawson, 2013) which often equates to between 50 and 499 employees (CBI, 2011). Recent longitudinal tracking research shows in the UK that only a tiny number of 'extraordinary prolific job creators' contribute disproportionately to the levels of job creation by HGFs (Anyadike-Danes et al., 2015). While greater attention is now being paid to these rare blockbuster successes in the media, academic research lags behind. ${ }^{2}$

Quite often these blockbuster successes occur in sectors where upscaling can occur very rapidly, such as software, fin-tech and digital media. It can also occur in less high-tech industries such as consumer-oriented sectors such as food and drink and through the adoption of disruptive business models in traditional industries (e.g. California's Uber). Unlike many HGFs, however, these major 'blockbuster' enterprises have powerful benefits for the wider EE in terms of demonstration effects and experiential learning for spin-offs, opportunities of serial entrepreneurship and the entrepreneurial re-cycling effects outlined above. These forces also engender a process of cumulative causation in terms blockbuster entrepreneurship. It seems no coincidence that Silicon Valley boosts 150 technology companies valued at more than a $\$ 1$ bn while a similarly sized European economy like Scotland has two such firms (Hoffman, 2015). ${ }^{3}$ Therefore, while blockbusters can emerge anywhere, they are more likely to emanate from highly developed EEs.

\subsection{Entrepreneurial resource providers}

Another key set of actors in EEs are entrepreneurial resource providers. In many ways these are the components of the entrepreneurial landscape which underpin the workings of the $\mathrm{EE}$ and enable the transfusion of resources into growing firms. Finance is a fundamental resource for start-ups and growth-oriented innovative firms (Cassar, 2004; Lerner, 2010; Lee et al., 2015). Financial providers include banks, venture capital firms and business angels (including syndicated groups).

\footnotetext{
${ }^{2}$ This is also evident in the latest animal metaphor, unicorn, being used to signify privately owned firms which reach a valuation of $\$ 1$ bn often within a very short space of time.

${ }^{3}$ Interestingly, the two Scottish firms are Fanduel and Skyscanner both digital media firms who are both heavily internationalised from inception-i.e. so-called 'born globals' (McDougall et al., 1994).
}

Increasingly, sources of alternative funding, such as peer-to-peer lending and crowdfunding have also been added to this entrepreneurial architecture (Bruton et al., 2015). The need for well a developed system or 'funding escalator' to help firms transition between different types of funding sources is critical to enable firms to grow and upscale (North et al., 2013; Schreiber and Pinelli, 2013).

Accelerators are a new addition to the types of specialist infrastructure available in many ecosystems. These 'startup factories' (Miller and Bound, 2011) which have grown very rapidly in recent years are designed to support or 'hothouse' growth-oriented new ventures via intensive coaching, funding and peer-based mentoring (Clarysse et al., 2015). This phenomenon has been particularly marked in key entrepreneurial growth nodes such as Silicon Valley, London and Berlin where start-up accelerators, such as Techstars, Y Combinator and Rocket Internet, have proliferated. They are also increasingly prevalent, in various hybrid forms, in less dynamic ecosystems such as Atlantic Canada and Scotland. Despite the increasing importance of this kind of entrepreneurial infrastructure, they have been largely ignored until recently by academic researchers (Clarysse et al., 2015). However, these accelerator programmes are helping to spawn a large number of growth-oriented start-ups in some ecosystems. In addition, in some ecosystems, major corporate firms are beginning to operate corporate accelerator programmes as a way of seeding new innovative firms (Becker and Gassmann, 2006).

In response to perceived market failures, the public sector has been actively involved in many ecosystems in helping to develop the types of resources outlined above (Mason and Brown, 2014). A particularly strong focus has been the creation of public sector sources of venture capital (Lerner, 2010; Nightingale et al., 2009), especially in parts of Europe (Grilli and Murtinu, 2014). This has included the creation of regional venture capital funds, usually taking a 'hybrid' form in which both public and private sector money is combined under private sector management. Underwriting the operating costs of business angel networks which operate as 'dating agencies' to enable investors and entrepreneurs seeking finance to more easily find one another has been another common form of support over the past 20 years (Mason, 2009). Despite substantial resources committed to this kind of activity, much remains unknown about their effectiveness (Mason, 2009). Many programmes 
operate in peripheral regions which display 'thin' risk capital markets (Nightingale et al., 2009). However, the state's role in ecosystems is a delicate balancing act. The limited research which has been done finds the performance of these public sector VC funds to be disappointing (Grilli and Murtinu, 2014) leading observers to argue that public intervention might be better channelled towards indirect support to foster private sector VC (Lerner, 2010; Grilli and Murtinu, 2014).

\subsection{Entrepreneurial connectors}

Networks are crucial for nascent ventures (Brüderl \& Preisendörfer, 1998). Dynamic EEs, typically have strong informal and formal networks which help alleviate resource deficiencies in start-ups and facilitate tacit knowledge sharing (Ferrary and Granovetter, 2009; Sullivan and Ford, 2014). Often dense ecosystems feature a myriad of different networking fora, business clubs, mentoring opportunities and start-up networks which act as the communal lifeblood of the ecosystem which develop a region's level of social capital (Malecki, 2012). A good example of this phenomenon is the CONNECT programme in San Diego which connects entrepreneurs with investors (Walshok et al. 2002; Audretsch, 2015).

Why do these mechanisms matter? Storper and Venables (2004) and Bathelt et al. (2004) have emphasised the importance of 'local buzz', a concept analogous to Marshall's concept of 'industrial atmosphere'. This 'refers to the information and communication ecology created by face-to-face contacts, copresence and co-location of people and firms within the same place or region' (Bathelt et al., 2004, p. 38). The buzz consists of specific information and continuous updates of this information, intended and unintended learning processes in organised and accidental meetings, the mutual understanding of new knowledge and technologies, as well as shared cultural traditions and habits within a particular technology field which stimulate the establishment of conventions and other institutional arrangements. Buzz relies on geography, but it also depends on the structure of local social relations and history of local interactions (Gertler, 2003).

This emphasis on the importance of deep-seated historical and cultural factors is in line with Becattini's (2004) influential analysis of the famous Italian industrial districts. Becattini talks about the importance of historical and cultural vestiges which foster inter-firm and inter-personal connections which encourage 'thickening'. This deeply socialised perspective of how firm behaviour operates in strong ecosystems is markedly different to most economists' views of Marshallian external economies and suggests 'what we have here is a very different socioeconomic brew' (Harrison, 1992, p. 117). So, while vibrant networks enable the valorisation of knowledge and ideas throughout an ecosystem, they are often highly context specific and heavily embedded in a complex set of social and cultural relations.

\subsubsection{The role of 'dealmakers'}

The relational interactions fostered by networks are crucial and are strongly orchestrated by the role of key individuals known variously as 'liaison-animateurs' (Sweeney, 1987) or 'dealmakers' (Senor and Singer, 2009; Napier and Hansen, 2011; Kemeny et al., 2015). These are individuals with 'valuable social capital, who have deep fiduciary ties within regional economies and act in the role of mediating relationships, making connections and facilitating new firm formation' (Feldman and Zoller, 2012, p. 24). Their active stewardship and financial involvement in multiple organisations 'embeds them in the regional entrepreneurial ecosystem' (Feldman and Zoller, 2012, p. 24), making them 'the glue in strong ecosystems' (Napier and Hansen, 2011, p. 13). Silicon Valley is perhaps the archetypal region with huge numbers of dealmakers whereas in less anaemic entrepreneurial economies 'they could gather in a single room' (Feldman and Zoller, 2012, p. 34).

Dealmakers are sometimes former entrepreneurs who invest in a range of firms, connecting people in their network and acting as a mentor to nascent entrepreneurs. The effect that Sir Terry Matthews has had on Ottawa's high-tech cluster offers a good example of the dealmaker phenomenon (Mason et al., 2002; Callaghan and Charbonneau, 2004; Mason and Brown, 2014). As well as being a serial entrepreneur, as a key dealmaker, he invested in more than 80 other firms in Ottawa (Mason and Brown, 2014). Feldman and Zoller (2012) show that firm births are closely associated with the prevalence of dealmakers, especially well-connected dealmakers like Matthews. Research across 12 US regions found dealmakers who use their connections to 'make things happen' exert a strong positive influence on recipients firms' employment and sales, but have no influence on the likelihood of them getting acquired (Kemeny et al., 2015, p2). 


\subsection{Entrepreneurial culture}

Culture and, specifically, positive societal norms and attitudes towards entrepreneurship, have been recognised as a key component of entrepreneurial ecosystems (Isenberg, 2011). For example, Brad Feld's (2012) work on entrepreneurship in Boulder, Colorado stressed the importance of an inclusive positive entrepreneurial culture as a key factor in the success of this ecosystem. This manifests itself in many connecting events fostering links between start-ups and larger firms.

By contrast, entrepreneurial aspirations will be inhibited in societies where the societal contribution of entrepreneurs is not valued, were the social status of entrepreneurs is low, where their financial success is resented and where failure is viewed negatively (Isenberg, 2010). Both perceptions of the desirability of entrepreneurship and the level of entrepreneurial activity which are measured in the Global Entrepreneurship Monitor (GEM) survey are fairly stable over time (also see Fritsch and Storey, 2014). Despite the efforts to change attitudes to entrepreneurship through entrepreneurship education and start-up campaigns, most of these initiatives prove unsuccessful (Van Stel and Storey, 2004; O'Conner, 2013). Most of the evidence shows a higher propensity to incorporate in developing countries, reflects greater levels of necessity entrepreneurship (Acs et al., 2008b). Therefore, high levels of entrepreneurship per se cannot be equated with dynamic economies (Isenberg and Brown, 2014; Mazzucato, 2014; Colombelli et al., 2016).

Moreover, there is a cumulative and reinforcing nature of low levels of entrepreneurship in many ecosystems (Venkataraman, 2004). Regions with the greatest numbers of entrepreneurs have the most positive attitude towards entrepreneurship as role models are more abundant. Not only that, but the types of entrepreneurs are also qualitatively different in some ecosystems in terms of their levels of ambition. While entrepreneurship scholars have tended to depict this as personal traits of the individual entrepreneurs (Lumpkin and Dess, 1996), other factors like culture, institutions and local networks all play a role too (Acs et al., 2008a; Gertler, 2010; Welter, 2011). Clearly, some ecosystems manage to develop and attract ambitious entrepreneurs while others do not (Saxenian, 2006). This is evident in the fact some locations see more start-ups scale up into larger businesses, large-scale exits and high levels of IPOs (Coutu, 2014). In some regions with low entrepreneurial cultures, many promising start-ups and HGFs become sold off prematurely (Mason et al., 2015; Spigel, 2015). ${ }^{4}$ Even the majority of the lauded Israeli start-up population end up being acquired by US firms (Senor and Singer, 2009). The exact reasons underpinning these processes are complex but as well as cultural factors, such as a lack of entrepreneurial ambition, it may also hinge on a lack of sufficiently developed levels of funding in some ecosystems. Therefore, negative aspects of ecosystems are also cumulative and selfreinforcing.

\section{Entrepreneurial ecosystems: measurement and conceptualisation}

\subsection{Measuring entrepreneurial ecosystems}

Most studies of the nature of entrepreneurial ecosystems have undertaken fairly rudimentary forms of assessment. This parallels the clusters literature which during its heyday in the 1990s became awash with studies attempting to measure them using techniques such as location quotients, shift-share and input-output analysis (Martin and Sunley, 2003). In a similar vein, studies of ecosystems often tend to use various indicators (or proxies) to measure the dynamism within any given ecosystem. Again, the driver is to monitor how policy is affecting EEs. According to Vogel (2013, p. 9), 'if we do not measure the effectiveness of the various components in an ecosystem as well as the ecosystems as a whole, we will not be able to improve existing programmes and put in place new and complementary resources'.

These measurement approaches are far from straightforward (Mason and Brown, 2014). Some authors have used 'dealmakers' as a proxy for the evidence of dynamism within ecosystems (Napier and Hansen, 2011; Feldman and Zoller, 2012). However, this kind of single indicator analysis is susceptible to misinterpretation and could over-emphasis a single constituent actor within EEs. The Danish Business development agency, the FORA Group, use four measures: deal makers (as defined earlier), venture capital, patents and location coefficients (Napier and Hansen, 2011). The Kauffman

\footnotetext{
${ }^{4}$ Interestingly, the locations featuring this exit mentality, such Calgary, Israel and Scotland, all feature high levels of foreign direct investment (FDI).
} 
Foundation has recently focused on the following four variables: density, fluidity, connectivity and diversity (Stangler and Bell-Masterson, 2015). The World Economic Forum has devised a more elaborate set of complex indices based on a vast array of variables (WEF, 2014). Others have used indices of national-level date to construct the Global Entrepreneurship Development Index (GEDI) (Acs et al., 2014). The problems with most of these indices is that they rely heavily on the availability of data and many are focused on the level of the nation state ignoring the specificities needed to interrogate regional ecosystems.

An alternative more localised approach to measurement is the Regional Entrepreneurship Accelerator Programme (REAP) which has been developed by The Massachusetts Institute of Technology (MIT) as a tool for policy makers to measure the regional entrepreneurship ecosystem using a combination of objective data (to measure 'activity pillars') and perceptual measures to identify bottlenecks and weaknesses (although strengths could also be identified in this way). While basic attempts have been made to operationalise these indices at the regional level (see Levie et al., 2013), these measurement approaches tend to focus on inputs (levels of risk capital) rather than outputs (such as levels of HGFs or levels of growth-ambition in entrepreneurs). The other issue of course is that most of them focus on issues predominantly concerning business start-ups.

While not without merit, these formulaic approaches are vulnerable to misinterpretation (Mason and Brown, 2014). For example, they tend to underplay the crucial importance of 'blockbuster' entrepreneurship and associated concepts like entrepreneurial re-cycling outlined above. They also ignore the importance of entrepreneurial orientation within the population, a factor which is cumulative and path dependent but has a huge bearing on EEs. More work is unquestionably needed to help develop more nuanced methods of measuring the multidimensional issues within EEs (Best, 2015; Mack and Mayer, 2015).

\subsection{Conceptualising entrepreneurial ecosystems}

To date, there has been little explicit theorisation around EEs which has undoubtedly hampered our understanding of these complex phenomenon. Given the primacy of resource scarcity within start-ups, Resource Dependency Theory might be one useful way of analysing the nature of ecosystems (Pfeffer, and Salancik, 2003).
Other theoretical concepts like 'dynamic capabilities' (Teece, 2007) offer scholars valuable opportunities for theoretisation. Whereas traditional economic development concepts highlight the need for resource accumulation, dynamic capabilities stress 'the importance of entrepreneurship, innovation, and good strategy' in the growth of some countries (Teece, 2014, 337). Indeed, the primary focus of dynamic capabilities is predicated on the entrepreneurial ability of firms to 'sense and seize' new growth opportunities which resonates with the premise underlying EEs (Teece, 2007).

Developing taxonomies is another important way for scholars to theorise around new concepts (Martin and Sunley, 2003). Just as the population of firms reveals considerable entrepreneurial diversity (Welter et al., 2016), so do ecosystems. We therefore propose a preliminary classification of different types of EEs and their underlying logic and dynamics to help us better conceptualise their fundamental dynamics similar in nature to the work classifying industrial districts (Markusen, 1996). Of course, a similar comprehensive typology of EEs would require a large-scale programme of in-depth comparative research which is beyond the scope of this paper. Until this is possible, a preliminary classification system is proposed below.

In order to advance our conceptual thinking, we outline a basic dichotomous framework between two diametrically opposed or 'idealised' types of ecosystems (see Table 1 below). ${ }^{5}$ The two identified are 'Embryonic ecosystems' and 'Scale-up ecosystems'. Embryonic ecosystems are by far the most dominant types of EEs. While there are a large number of different such ecosystems with their own deep-seated idiosyncrasies, they all have certain commonalities. Typically, these areas are characterised by a relatively modest levels of growthoriented entrepreneurship. Such locations have relatively low levels of high-tech start-ups and less welldeveloped levels of entrepreneurial orientation compared to the more advanced 'scale-up ecosystems'.

While all ecosystems share some of the features associated with well-developed EEs, such as a spatial logic and a level of relational interactivity, those in the embryonic category are not as fully developed as the more fully rounded 'scale-up' variants highlighted below. For example, many are geographically centred in one location and are based around a core cluster or

\footnotetext{
$\overline{5}$ The authors are grateful to one of the referees for helping clarify their thinking in terms of their ecosystem taxonomy.
} 
Table 1 A basic typology of entrepreneurial ecosystems

\begin{tabular}{|c|c|c|}
\hline Ecosystem dynamics & Embryonic ecosystem & Scale-up ecosystem \\
\hline Dominant actors & $\begin{array}{l}\text { Limited numbers of start-ups. Established incumbent } \\
\text { firms are the bedrock of the local economy and often } \\
\text { drive the start-up process. }\end{array}$ & $\begin{array}{l}\text { High numbers of growth-oriented start-ups. Large } \\
\text { numbers of rapidly growing ambitious companies } \\
\text { (e.g. HGFs). Unicorns dominate the landscape } \\
\text { spawning more start-ups. }\end{array}$ \\
\hline $\begin{array}{l}\text { Nature of ecosystem } \\
\text { interactions }\end{array}$ & $\begin{array}{l}\text { Limited interactions within the start-up ecosystem. Weak } \\
\text { vertical interactions between start-ups, larger firms } \\
\text { and sources of growth capital. }\end{array}$ & $\begin{array}{l}\text { Strong levels of interactions within start-ups. Large } \\
\text { rapidly growing firms heavily configure the } \\
\text { ecosystem architecture. Strong vertical inter-actor } \\
\text { networks. }\end{array}$ \\
\hline $\begin{array}{l}\text { Levels of } \\
\text { entrepreneurial } \\
\text { orientation }\end{array}$ & $\begin{array}{l}\text { Low. Start-ups focus on early and/or premature exits. } \\
\text { HGFs frequently acquired by foreign multinationals. }\end{array}$ & $\begin{array}{l}\text { High. Strong growth-focus on generating new } \\
\text { 'blockbuster' firms (e.g. IPOs) }\end{array}$ \\
\hline $\begin{array}{l}\text { Nature of funding } \\
\text { escalator and } \\
\text { availability of } \\
\text { funding }\end{array}$ & $\begin{array}{l}\text { Funding driven by the needs of start-ups, good sources of } \\
\text { seed and early stage funding, often publicly funded } \\
\text { through co-investment schemes. }\end{array}$ & $\begin{array}{l}\text { Full range of funding sources across the entire funding } \\
\text { escalator. Nearly all privately funded. }\end{array}$ \\
\hline $\begin{array}{l}\text { Importance and role of } \\
\text { dealmakers }\end{array}$ & $\begin{array}{l}\text { Limited numbers of dealmakers, tend to dominate most } \\
\text { key deals focused on single sectors. }\end{array}$ & $\begin{array}{l}\text { Large numbers of dealmakers with strong inter-regional } \\
\text { and cross-sectoral connectivity }\end{array}$ \\
\hline $\begin{array}{l}\text { Fluidity and diversity } \\
\text { of ecosystem actors }\end{array}$ & $\begin{array}{l}\text { Predominantly locally domiciled entrepreneurs, low } \\
\text { levels of 'transnational entrepreneurs'. }\end{array}$ & $\begin{array}{l}\text { Large numbers of entrepreneurs are non-native, } \\
\text { immigration of 'transnational entrepreneurs' is high }\end{array}$ \\
\hline $\begin{array}{l}\text { Level of } \\
\text { "Blockbuster" } \\
\text { entrepreneurship }\end{array}$ & $\begin{array}{l}\text { Limited, but sometime occasional 'blockbusters' } \\
\text { entrepreneurial 'events' }\end{array}$ & $\begin{array}{l}\text { Frequent blockbusters leads to a cumulative process } \\
\text { which generates a virtuous cycle of blockbuster } \\
\text { 'events' }\end{array}$ \\
\hline $\begin{array}{l}\text { Nature of } \\
\text { entrepreneurial re- } \\
\text { cycling }\end{array}$ & $\begin{array}{l}\text { Small number of major exits. } \\
\text { Low levels of entrepreneurial re-cycling, but limited to } \\
\text { small projects. Limited number of angels, mostly } \\
\text { syndicated and co-investment with government } \\
\text { sources of venture capital. }\end{array}$ & $\begin{array}{l}\text { Large number of blockbuster 'exits'. Substantial levels of } \\
\text { re-cycling and experiential learning for serial } \\
\text { entrepreneurs. Large number of high net worth } \\
\text { individuals who become angels. }\end{array}$ \\
\hline Spatial dynamics & $\begin{array}{l}\text { Mostly locally focused with some connections to other } \\
\text { national interactions for funding, human capital and } \\
\text { innovation }\end{array}$ & $\begin{array}{l}\text { Strong local, national and global interactions. Resources } \\
\text { are drawn from a myriad of different sources and } \\
\text { actors }\end{array}$ \\
\hline $\begin{array}{l}\text { Importance and focus } \\
\text { of public policy }\end{array}$ & $\begin{array}{l}\text { Strong role for policy, typically focuses on increasing } \\
\text { resources (especially funding) to new technology- } \\
\text { based firms (NTBFs) }\end{array}$ & $\begin{array}{l}\text { Limited role for policy, many initiatives are industry-led } \\
\text { and focus on building vertical network connectivity } \\
\text { across the ecosystem }\end{array}$ \\
\hline $\begin{array}{l}\text { Archetypal empirical } \\
\text { examples }\end{array}$ & $\begin{array}{l}\text { Scotland, Ireland, Milwaukee, } \\
\text { Finland, Portugal. }\end{array}$ & $\begin{array}{l}\text { Silicon Valley, Cambridge (UK), } \\
\text { Cambridge (MA), Waterloo, Tech City in London and } \\
\text { Berlin }\end{array}$ \\
\hline
\end{tabular}

clusters of related industrial activities like the oil and gas industry in Calgary (Spigel, 2015). Indeed, work in Scotland found that nearly a third of Scottish HGFs relied on the oil and gas sector for the majority of their revenue (Mason et al., 2015). This sectoral dependency clearly makes some of these firms heavily dependent on a cyclical resource. ${ }^{6}$ While this can make some single industry-based ecosystems more susceptible to economic shocks due to the narrowness of their economic and export base- oil-based regions perhaps being the best illustration of this process - it can also have other unintended effects. Ecosystems which are dominated by a single sector may encounter entrepreneurial 'crowding out' where human capital gravitates towards a single industry to the exclusion of other innovative sectors and entrepreneurial activities. These deleterious impacts would appear to be more engrained and acute in locations dominated by foreign investment (Pathak et al., 2015).

Other embryonic ecosystems have cohesive internal interactions and are quite self-contained but lack a depth

\footnotetext{
${ }^{6}$ Of course, export markets offer firms the opportunity to reduce their dependency on local markets. Becoming more export-oriented also has important firm-level effects by enhancing their innovativeness, the socalled "learning by exporting hypothesis", especially for small and young firms (Gkypali et al., 2015).
} 
of connections and diversity of entrepreneurial actors. A lack of big 'exits' reduces the chance for significant levels of entrepreneurial re-cycling. Often, dealmakers are limited in number and confined to particular sectors (Feldman and Zoller, 2012). Blockbuster entrepreneurship occurs in embryonic ecosystems, however, such big wins are likely to remain very rare occurrences and may not have the levels of embeddedness or traction within the local economy commonplace in more advanced EEs. This could be shaped by a lack of local human capital, market access or access to growth capital such as VCs or access to stock markets for IPOs etc. Blockbuster entrepreneurship is a necessary but insufficient condition to become a scaled-up EE.

Turning our attention to the 'scale-up' variant depicted in Table 1 reveals a quite different configuration of actors, resource providers, entrepreneurial connectors and entrepreneurial outlooks transposed within these more developmental ecosystems. These are much less common forms of EEs and are mostly located in core economic regions or capital cities, like Silicon Valley, London, Berlin and New York. University towns, like Cambridge in England and Cambridge, MA and Waterloo in Ontario, also exemplify certain features of these ecosystems benefitting, as they do, from a critical mass of university spin-outs, high levels of human capital and strong proximity to major urban conurbations. Indeed, a strong form of differentiation between scale-up and embryonic ecosystems is the former's close bonds to other entrepreneurial growth nodes for transnational entrepreneurs, resources (especially finance) and connections to other resources. Typically speaking, these more rounded ecosystems are predicated on a variety of different clusters, and industries, with many heavily skewed towards high-tech. This ensures that sectoral downturns rarely or indefinitely lead to downturns, ensuring they foster a diverse range of sectors (Best, 2015).

These locations have a much higher level of start-ups than embryonic ecosystems, but this is not their defining characteristic. Instead, it is the ability of these locations to produce, support and nourish the growth of firms into larger corporate entities which marks these locations out from their less developed counterpart. This is done via a formidable level of social capital which aids the relational dynamism of the economy. Start-ups are intimately connected to dealmakers, who in turn help translate embryonic ventures into growth-oriented firms. Sources of funding are comprehensive and pools of 'smart money' are strong (Lange et al., 2001; Mason, 2009). This eases the transition of firms up the financial escalator from seed, to business angel investment to venture capital and then onwards to IPOs. This transition is eased by the close relationships which mesh business angels, entrepreneurs and financial firms often coordinated by key entrepreneurial dealmakers in these regions. Blockbuster entrepreneurship therefore becomes frequent and self-perpetuating. As Isenberg (2011, p. 9) states, 'the ecosystem is strengthened, which generates more entrepreneurs, which strengthens the ecosystem. Success breeds success'.

A binary classification system such as this is not without limitations of course and not all ecosystems will have all the features delineated above. The EE concept is a dynamic one so these ecosystems must be viewed as archetypal examples with empirical reality appearing somewhere in between. While some will improve and strengthen over time towards the scale-up variant, others may go into decline moving in the opposite direction. However, our central point is that the more a location resembles the scale-up model, the greater the propensity it will have to generate significant positive externalities and opportunities for its key entrepreneurial constituents.

\section{A critique of emergent policy frameworks}

A growing number of supranational bodies like the OECD, national governments, think tanks and economic agencies around the world are actively embracing the ecosystems concept as a tool for policy making in the sphere of entrepreneurship (Coutu, 2014; Mazzarol, 2014; WEF, 2014; Stam, 2015). However, policy formulation runs the danger of running ahead of its theoretical and empirical underpinnings. Given the fundamental peculiarities and specificities within the internal workings and dynamics of ecosystems, there is no standardised strategy for effectively developing EEs (Audretsch, 2015). Yet, from our reading of most ecosystem policy frameworks, the adoption of bespoke policy frameworks does not seem immediately evident. ${ }^{7}$

\footnotetext{
${ }^{7}$ One common form of policy focus is on environmental technologies to help develop ecosystems (Cohen, 2006). Indeed, some have noted that the distinction between environmental and innovation policies is becoming increasingly blurred owing to the upsurge of policies aim at developing environmental technologies (Crespi et al., 2015).
} 
Three main beliefs seem strongly embedded in current policy approaches. First, when policy makers refer to the ecosystems concept they invariably pre-fix the term with the term 'start-up' (see, Schreiber and Pinelli, 2013; WEF 2014). This could be labelled the 'start-up monoculture' (Stangler, 2015). This can be damaging for several reasons. It ignores the fact that the needs of firms change as they evolve. For example, if new ventures grow and upscale they will need to migrate away from the actors and interactions which facilitated their initial development. By just focusing on start-ups, some ecosystems may not have the full range of actors and interactions necessary to upscale businesses. In many economies, there are sufficient new entrants (Acs et al., 2016) but insufficient quality entrants (Nightingale and Coad, 2014). Consequently, the view that a focus on start-ups is 'bad public policy' (Shane, 2009) has gained currency, arguing that policy should focus on growthoriented firms instead (Mason and Brown, 2013). Other scholars claim much greater focus should be granted to promoting innovative start-ups rather than the majority of start-ups who engage in 'copycat' entrepreneurship (Colombelli et al., 2016).

Equating ecosystems purely with start-ups is therefore misconceived and potentially misleading (Isenberg, 2011; Mason and Brown, 2014). Ecosystems need more innovative scale-ups and blockbusters (Napier and Hansen, 2011; Coutu, 2014), indicative of a shift in policy on quality rather than quantity of entrepreneurship (Stam, 2015). How this translates into concrete policy proposals is a challenging task given the considerable difficulties of identifying firms with 'blockbuster potential'. While not wishing to offer specific policy prescriptions to help firms scale-up, policy makers will most likely require a different set of policy instruments to those designed to promote entrepreneurial entry. In this respect, peer-based relational support mechanisms which foster 'adaptability, enhance the dynamic capabilities and increase the outward orientation of firms' may be more effective than traditional transactional forms of support such as grants and assistance with funding typically targeted towards HGFs (Brown and

\footnotetext{
${ }^{8}$ Interestingly, the UK Prime Minister, Theresa May, claims that the UK government "will act to turn our bright start-ups into successful scale-ups" by launching a review into the funding issues holding back firms seeking to scale up (Financial Times, 2016, p. 13). Seemingly, this presupposes financial obstacles are the core stumbling block for growth-oriented firms, despite evidence to the contrary (Binks and Ennew, 1996; Vos et al., 2007).
}

Mawson, 2016, p. 830). Given start-ups programmes have proved highly ineffective at counteracting the powerful path-dependent nature of entrepreneurship within economies (Van Stel and Storey, 2004; Fritsch and Storey, 2014), designing appropriate policies to foster scale-ups may prove equally illusive. ${ }^{8}$

The second core element embodied in current policy frameworks is the overwhelming focus on technology-based form (TBFs), and university spinoff companies (USCs) in particular. This is common in cluster policies, innovation policies and most entrepreneurship policies (Brown and Mason, 2014). This often entails high-tech firms being accorded a central place as dynamic drivers of knowledge-based economies. However, this emphasis on high-tech firms is incompatible with the composition and industrial structure found in most ecosystems. It is virtually impossible in regions lacking high-tech industries to build a strong technology base (Qian et al., 2013). By heavily promoting these forms of activities in economies with little prior core competencies or advantages, policy makers are ignoring the evolutionary logic and path-dependencies which shape their home environments. Given that most successful ecosystems typically build upon existing agglomerative forces based on particular industries or groups of industries, ensuring that these existing competencies are developed is vitally important (Isenberg, 2011; Best, 2015). If scaling-up firms is the hallmark of successful ecosystems, it would appear that the promotion of firms irrespective of their sectoral background should be a feature of systemic entrepreneurship policies.

A final feature that is evident in many of the 'new' policy frameworks is their reliance on traditional narrowly-based policy interventions. The vast majority of interventions promoted under the auspices of ecosystems strongly resemble single-actor interventions-utilised under other conceptual frameworks like clusters, innovation systems and learning regions (e.g. promoting start-ups, fostering networks, incubators, public sector VC etc.) — which focus on assisting the creation and growth of hightech firms. Most interventions target particular network actors, be they entrepreneurs, universities or firms. While this kind of support can benefit somethe Arch Grants programme in St Louis being one such example (Motoyama and Knowlton, 2016) this does not in itself constitute systemic 
entrepreneurship policy. Unlike the field of innovation policy which reveals considerable experimentation with systemic interventions designed to assist and connect innovation systems as a whole (Smits and Kuhlman, 2004; Wieczorek and Hekkert, 2012), entrepreneurship policy rarely attempts to help foster vertical connections across ecosystems. Yet arguably, in order to help foster 'blockbuster entrepreneurship' more system-wide and outward-oriented approaches are likely to be more effective. ${ }^{9}$

\section{Conclusions}

Like others, we see considerable merit in adopting a systemic approach to aid our understanding of the world's entrepreneurial 'spiky bits'. The strength of this concept is, undoubtedly, the emphasis it places on the role of entrepreneurial 'agency' in shaping EEs. However, when examining EEs it is important both structure and agency are examined together to appreciate the full complexity of the dynamics of entrepreneurial activity in any given context. At present, scholars and policy makers have failed to comprehend the full complexity of these complex organisms. Crude forms of measurement approaches towards EEs could potentially amplify this problem. Our proposed taxonomy is therefore an attempt to delineate this complex, variegated and temporally discontinuous phenomena.

Importantly, misconceptions about the nature and functioning of entrepreneurial ecosystems create the potential for misconceived policy interventions, signified by the continued emphasis on start-ups and the lack of genuinely systemic policy instruments. ${ }^{10}$ Given their pervasive heterogeneity, there is unlikely to be a 'onesize fits all' policy prognosis for developing different types of ecosystems. Scholars therefore need to further dissect, conceptualise, theorise and empirically examine this complex phenomenon much more closely to move our understanding forward. This paper aims to provide a start in this direction.

\footnotetext{
${ }^{9}$ One such example is the Yozma programme operated by the Israeli government which helps attract foreign $\mathrm{VC}$ to local entrepreneurial firms and is credited with the rapid growth of many of the country's growing high-tech economy (Lerner, 2010).

${ }^{10}$ These misconceptions are also strongly evident in other aspects of entrepreneurship policy (see Brown, et al., 2017).
}

Acknowledgements The authors wish to thank the Organisational for Economic Cooperation and Development (OECD) for funding their original research on entrepreneurial ecosystems. In particular, they acknowledge the support received from Marco Marchese and Jonathan Potter from the OECD. Earlier versions of the paper were presented at the OECD 'Entrepreneurial Ecosystems and Growth Oriented Entrepreneurship' conference held at The Hague, Netherlands, 7th November 2013 and the Entrepreneurial Ecosystems Symposium held at the University of Adelaide on 14-15 June 2016. We wish to thank the participants for their helpful comments. Dan Isenberg's comments on earlier drafts of the manuscript were particularly insightful. The authors also wish to thank the comments received on the paper from the Editors and the anonymous referees. The usual disclaimer applies.

Open Access This article is distributed under the terms of the Creative Commons Attribution 4.0 International License (http:// creativecommons.org/licenses/by/4.0/), which permits unrestricted use, distribution, and reproduction in any medium, provided you give appropriate credit to the original author(s) and the source, provide a link to the Creative Commons license, and indicate if changes were made.

\section{References}

Acs, Z. J., Desai, S., \& Hessels, J. (2008a). Entrepreneurship, economic development and institutions. Small Business Economics, 31(3), 219-234.

Acs, Z. J., Desai, S., \& Klapper, L. F. (2008b). What does "entrepreneurship" data really show? Small Business Economics, 31(3), 265-281.

Acs, Z. J., Autio, E., \& Szerb, L. (2014). National systems of entrepreneurship: Measurement issues and policy implications. Research Policy, 43(3), 476-494.

Acs, Z., Åstebro, T., Audretsch, D., \& Robinson, D. T. (2016). Public policy to promote entrepreneurship: A call to arms. Small Business Economics, 47(1), 35-51.

Adams, S. B. (2011). Growing where you are planted: exogenous firms and the seeding of Silicon Valley. Research Policy, 40(3), 368-379.

Amit, R., MacCrimmon, K. R., Zietsma, C., \& Oesch, J. M. (2001). Does money matter?: Wealth attainment as the motive for initiating growth-oriented technology ventures. Journal of Business Venturing, 16(2), 119-143.

Anyadike-Danes, M., Hart, M., \& Du, J. (2015). Firm dynamics and job creation in the United Kingdom: 1998-2013. International small business journal, 33(1), 12-27.

Asheim, B. T., Boschma, R., \& Cooke, P. (2011). Constructing regional advantage: Platform policies based on related variety and differentiated knowledge bases. Regional Studies, 45(7), 893-904.

Audretsch, D. B. (2015). Everything in its place: Entrepreneurship and the strategic Management of Cities, regions, and states. Oxford: Oxford University Press.

Audretsch, D. B., \& Belitski, M. (2016). Entrepreneurial ecosystems in cities: establishing the framework conditions. The 
Journal of Technology Transfer. doi:10.1007/s10961-0169473-8.

Autio, E., Kenney, M., Mustar, P., Siegel, D., \& Wright, M. (2014). Entrepreneurial innovation: the importance of context. Research Policy, 43(7), 1097-1108.

Baker, T., \& Nelson, R. E. (2005). Creating something from nothing: resource construction through entrepreneurial bricolage. Administrative Science Quarterly, 50(3), 329-366.

Bathelt, H., Malmberg, A., \& Maskell, P. (2004). Clusters and knowledge: local buzz, global pipelines and the process of knowledge creation. Progress in Human Geography, 28(1), 31-56.

Baumol, W. J. (1996). Entrepreneurship: Productive, unproductive, and destructive. Journal of Business Venturing, 11(1), 3-22.

Becattini, G. (2004). Industrial districts: A new approach to industrial change. Chelteham: Edward Elgar Publishing.

Becker, B., \& Gassmann, O. (2006). Gaining leverage effects from knowledge modes within corporate incubators. $R \& D$ Management, 36(1), 1-16.

Best, M. H. (2015). Greater Boston's industrial ecosystem: a manufactory of sectors. Technovation, 39, 4-13.

Binks, M. R., \& Ennew, C. T. (1996). Growing firms and the credit constraint. Small Business Economics, 8(1), 17-25.

Borissenko, Y., \& Boschma, R. (2016). A critical review of entrepreneurial ecosystems: towards a future research agenda, No 1630. Section of Economic Geography: Utrecht University.

Brüderl, J., \& Preisendörfer, P. (1998). Network support and the success of newly founded business. Small Business Economics, 10(3), 213-225.

Brown, R., \& Mawson, S. (2013). Scotland's companies of scale Programme. In An international benchmarking analysis of public programmes for high-growth firms (pp. 64-84). Paris: OECD.

Brown, R., \& Mason, C. (2014). Inside the high-tech black box: a critique of technology entrepreneurship policy. Technovation, 34(12), 773-784.

Brown, R. (2016). Mission impossible? Entrepreneurial universities and peripheral regional innovation systems. Industry and Innovation, 23(2), 189-205.

Brown, R., \& Mawson, S. (2016). Targeted support for high growth firms: theoretical constraints, unintended consequences and future policy challenges. Environment and Planning C: Government and Policy, 34(5), 816-836.

Brown, R., Mawson, S., \& Mason, C. (2017). Myth-busting and entrepreneurship policy: the case of high growth firms. Entrepreneurship \& Regional Development. doi:10.1080 /08985626.2017.1291762.

Bruton, G., Khavul, S., Siegel, D., \& Wright, M. (2015). New financial alternatives in seeding entrepreneurship: microfinance, crowdfunding, and peer-to-peer innovations. Entrepreneurship Theory and Practice, 39(1), 9-26.

Buenstorf, G., \& Fornahl, D. (2009). B2C - bubble to cluster: the dot-com boom, spin-off entrepreneurship, and regional agglomeration. Journal of Evolutionary Economics, 19(3), 349-378.

Callaghan, J and Charboneau, K (2004) The role of venture capital in building technology companies in the Ottawa region. In L V Shavinina (ed) Silicon Valley North: Technology, Innovation, Entreprenuership and Competitve Capacity. Emerald, pp 169-201.
Carlsson, B., Jacobsson, S., Holmén, M., \& Rickne, A. (2002). Innovation systems: analytical and methodological issues. Research Policy, 31(2), 233-245.

Cassar, G. (2004). The financing of business start-ups. Journal of Business Venturing, 19(2), 261-283.

CBI (2011) Future champions: unlocking growth in the UK's medium-sized business, Confederation of British Industry, London. Download from: http://www.cbi.org. uk/media/1125696/cbi_future_champions_report.pdf

Clarysse, B., Wright, M., \& VanHove, J. (2015). A look inside accelerators. London: Nesta.

Cohen, B. (2006). Sustainable valley entrepreneurial ecosystems. Business Strategy and the Environment, 15(1), 1-14.

Colombelli, A., Krafft, J., \& Vivarelli, M. (2016). To be born is not enough: the key role of innovative start-ups. Small Business Economics, 1-15.

Colombo, M. G., \& Grilli, L. (2007). Funding gaps? Access to bank loans by high-tech start-ups. Small Business Economics, 29(1-2), 25-46.

Cooke, P., Uranga, M. G., \& Etxebarria, G. (1997). Regional innovation systems: Institutional and organisational dimensions. Research Policy, 26(4), 475-491.

Coutu, S. (2014). The scale up report on UK economic growth, An independent report to the UK government. http://www. scaleupreport.org/scaleup-report.pdf

Crespi, F., Ghisetti, C., \& Quatraro, F. (2015). Environmental and innovation policies for the evolution of green technologies: a survey and a test. Eurasian Business Review, 5(2), 343-370.

Dahl, M. S., \& Sorenson, O. (2009). The embedded entrepreneur. European Management Review, 6(3), 172-181.

Daunfeldt, S. O., \& Halvarsson, D. (2015). Are high-growth firms one-hit wonders? Evidence from Sweden. Small Business Economics, 44(2), 361-383.

De Massis, A., Audretsch, D., Uhlander L., and Kammerlander N. (2017) Innovation with limited Resources: Management Lessons from the German Mittelstand, Journal of Product Innovation Management, published online DOI: 10.1111 /jpim. 12373.

Delgado, M., Porter, M. E., \& Stern, S. (2010). Clusters and entrepreneurship. Journal of Economic Geography, 10(4), 495-518.

Drori, I., Honig, B., \& Wright, M. (2009). Transnational entrepreneurship: an emergent field of study. Entrepreneurship Theory and Practice, 33(5), 1001-1022.

Eliasson, G., \& Eliasson, A. (1996). The biotechnological competence bloc.Revue d'Economie. Industrielle, 78(1), 7-26.

Eliasson, G. (2000). Industrial policy, competence blocs and the role of science in economic development. Journal of Evolutionary Economics, 10(1-2), 217-241.

Feld, B. (2012). Startup communities: building an entrepreneurial ecosystem in your city. John Wiley \& Sons.

Feldman, M., Francis, J., \& Bercovitz, J. (2005). Creating a cluster while building a firm: Entrepreneurs and the formation of industrial clusters. Regional Studies, 39(1), 129-141.

Feldman, M., \& Braunerhjelm, P. (2006). The genesis of industrial clusters. Cluster genesis: Technology-based industrial development, 1, 1-13.

Feldman, M., \& Zoller, T. D. (2012). Dealmakers in place: social capital connections in regional entrepreneurial economies. Regional Studies, 46(1), 23-37. 
Feldman, M. P. (2014). The character of innovative places: entrepreneurial strategy, economic development, and prosperity. Small Business Economics, 43(1), 9-20.

Feldman, M. P., \& Tavassoli, S. M. (2015). Something new. In D. Audretsch, A. Link, \& M. Walshok (Eds.), The Oxford Handbook of Local Competitiveness (pp. 125-140). New York: Oxford University Press.

Ferrary, M., \& Granovetter, M. (2009). The role of venture capital firms in Silicon Valley's complex innovation network. Economy and Society, 38(2), 326-359.

Times, F. (2016). The new role for business in a fairer Britain. Financial Times, Monday $21^{\text {st }}$, (November).

Florida, R. (2005). The world is spiky: globalization has changed the economic playing field, but hasn't leveled it. Atlantic Monthly, 296(3), 48.

Freeman, C. (1995). The 'National System of Innovation' in historical perspective. Cambridge Journal of Economics, 19(1), 5-24.

Fritsch, M., \& Storey, D. J. (2014). Entrepreneurship in a regional context: historical roots, recent developments and future challenges. Regional Studies, 48(6), 939-954.

Fujita, M., Krugman, P. R., \& Venables, A. (2001). The spatial economy: cities, regions, and international trade. MIT press.

Garnsey, E. (1998). A theory of the early growth of the firm. Industrial and Corporate Change, 7(3), 523-556.

Garnsey, E., \& Heffernan, P. (2005). High-technology clustering through spin-out and attraction: The Cambridge case. Regional Studies, 39(8), 1127-1144.

Gertler, M. S. (2003). Tacit knowledge and the economic geography of context, or the undefinable tacitness of being (there). Journal of economic geography,3(1), 75-99.

Gertler, M. S. (2010). Rules of the game: the place of institutions in regional economic change. Regional Studies, 44(1), 1-15.

Glückler, J. (2007). Economic geography and the evolution of networks. Journal of Economic Geography, 7(5), 619-634.

Guerrero, M., Urbano, D., Fayolle, A., Klofsten, M., \& Mian, S. (2016). Entrepreneurial universities: emerging models in the new social and economic landscape. Small Business Economics, 1-13.

Gkypali, A., Rafailidis, A., \& Tsekouras, K. (2015). Innovation and export performance: do young and mature innovative firms differ? Eurasian Business Review, 5(2), 397-415.

Harrison, B. (1992). Industrial districts: old wine in new bottles? Regional Studies, 26(5).

Harrison, R. T., Mason, C. M., \& Robson, P. J. A. (2010). Determinants of long-distance investing by business angels in the UK. Entrepreneurship and Regional Development, 22(2), 113-137.

Henrekson, M., \& Johansson, D. (2010). Gazelles as job creators: a survey and interpretation of the evidence. Small Business Economics, 35(2), 227-244.

Hoffman, R. (2015) Expertise in scaling up is the visible secret of Silicon Valley, $15^{\text {th }}$ September, http://www.ft.com/cms/s/0 /39001312-4836-11e5-af2f-4d6e0e5eda22.html\#axzz3 nEsskiy8

Hospers, G. J. (2006). Silicon somewhere? Assessing the usefulness of best practices in regional policy. Policy studies, 27(1), $1-15$.

Kantis, H. D., \& Federico, J. S. (2012). Entrepreneurial ecosystems in Latin America: the role of policies. In International research and policy roundtable (Kauffman Foundation). Liverpool: UK.

Kemeny, T., Feldman, M., Ethridge, F., \& Zoller, T. (2015). The economic value of local social networks. Journal of Economic Geography. doi:10.1093/jeg/1bv043.

Krugman, P. R. (1991). Geography and trade. MIT press.

Isenberg, D. J. (2010). How to start an entrepreneurial revolution. Harvard Business Review, 88(6), 40-50.

Isenberg, D. (2011). The entrepreneurship ecosystem strategy as a new paradigm for economic policy: Principles for cultivating entrepreneurship. Presentation at the Institute of International and European Affairs.

Isenberg, D. and Brown, R. (2014) For a booming economy, bet on high-growth firms, Not Small Businesses. Babson Entrepreneurship Ecosystem Project. Retrieved from http://blogs.hbr.org/2014/02/for-a-booming-economy-beton-high-growth-firms-not-small-businesses/

Isenberg, D., \& Onyemah, V. (2016). Fostering scaleup ecosystems for regional economic growth. Innovations, 11(1-2), 60-79.

Lange, J. E., Bygrave, W., Nishimoto, S., Roedel, J., \& Stock, W. (2001). Smart money? The impact of having top venture capital investors and underwriters backing a venture. Venture Capital: an international journal of entrepreneurial finance, 3(4), 309-326.

Lee, N. (2014). What holds back high-growth firms? Evidence from UK SMEs. Small Business Economics, 43(1), 183-195.

Lee, N., Sameen, H., \& Cowling, M. (2015). Access to finance for innovative SMEs since the financial crisis. Research Policy, 44(2), 370-380.

Lee, N., Brown, R. and Schulter, T. (2016) Modes of firm growth, research paper no 46, Enterprise Research Centre. http://www.enterpriseresearch.ac.uk/publications/modesfirm-growth/

Levie, J., Autio, E., Reeves, J., Chisholm, D., Harris, J., Grey, S., Ritchie, I., \& Cleevely, M. (2013). Assessing regional innovative entrepreneurship ecosystems with the global entrepreneurship and development index: the case of Scotland. Hunter Centre for Entrepreneurship: University of Strathclyde.

Lerner, J. (2010). The future of public efforts to boost entrepreneurship and venture capital. Small Business Economics, 35(3), 255-264.

Levin, S. A. (1998). Ecosystems and the biosphere as complex adaptive systems. Ecosystems, 1(5), 431-436.

Lumpkin, G. T., \& Dess, G. G. (1996). Clarifying the entrepreneurial orientation construct and linking it to performance. Academy of management Review, 21(1), 135-172.

Lundvall, B. Å. (2010). National systems of innovation: Toward a theory of innovation and interactive learning (Vol. 2). Anthem press.

Mack, E., \& Mayer, H. (2015). The evolutionary dynamics of entrepreneurial ecosystems. Urban Studies. doi:10.1177 $/ 0042098015586547$.

Malecki, E. J. (2011). Connecting local entrepreneurial ecosystems to global innovation networks: open innovation, double networks and knowledge integration. International Journal of Entrepreneurship and Innovation Management, 14(1), 3659.

Malecki, E. J. (2012). Regional social capital: why it matters. Regional Studies, 46(8), 1023-1039. 
Markusen, A. (1996). Sticky places in slippery space: a typology of industrial districts. Economic Geography, 293-313.

Markusen, A. (1999). Fuzzy concepts, scanty evidence, policy distance: the case for rigour and policy relevance in critical regional studies. Regional Studies, 33(9), 869-884.

Marshall, A. (1890). Principles of economics. London: Macmillan.

Martin, R. (1999). Critical survey. The new 'geographical turn' in economics: some critical reflections. Cambridge Journal of Economics, 23(1), 65-91.

Martin, R., \& Sunley, P. (2003). Deconstructing clusters: chaotic concept or policy panacea? Journal of Economic Geography, $3(1), 5-35$.

Martin, R., \& Sunley, P. (2011). Conceptualizing cluster evolution: beyond the life cycle model? Regional Studies, 45(10), 1299-1318.

Martin, R. (2015). Rebalancing the spatial economy: the challenge for regional theory. Territory, Politics, Governance, (aheadof-print), 1-38.

Mason, C., Cooper, S., \& Harrison, R. (2002). Venture capital and high technology clusters: the case of Ottawa. In R. Oakey, W. During, \& S. Kauser (Eds.), New Technology-Based Firms in the New Millennium, Volume II (Pergammon) (pp. 261-278).

Mason, C. M., \& Harrison, R. T. (2006). After the exit: Acquisitions, entrepreneurial recycling and regional economic development. Regional Studies, 40(1), 55-73.

Mason, C. M. (2009). Public policy support for the informal venture capital market in Europe a critical review. International Small Business Journal, 27(5), 536-556.

Mason, C., \& Brown, R. (2013). Creating good public policy to support high-growth firms. Small Business Economics, 40(2), 211-225.

Mason, C., \& Brown, R. (2014). Entrepreneurial ecosystems and growth oriented entrepreneurship. Paris: Final Report to OECD http://lib.davender.com/wp-content/uploads/2015/03 /Entrepreneurial-ecosystems-OECD.pdf.

Mason, C., Brown, R., Hart, M., \& Anyadike-Danes, M. (2015). High growth firms, jobs and peripheral regions: the case of Scotland. Cambridge Journal of Regions, Economy and Society, rsu032.

Mayer, H. (2013). Entrepreneurship in a hub-and-spoke industrial district: Firm survey evidence from Seattle's technology industry. Regional Studies, 47(10), 1715-1733.

Mazzarol, T. (2014) Growing and sustaining entrepreneurial ecosystems: What they are and the role of government policy, Small Enterprise Association of Australia and New Zealand, SEAANZ white paper WP01-2014.

Mazzucato, M. (2014) Start-up myths and obsessions, The Economist, February $3^{\text {rd }} 2014$. http://www.economist. com/blogs/schumpeter/2014/02/invitation-marianamazzucato

McDougall, P. P., Shane, S., \& Oviatt, B. M. (1994). Explaining the formation of international new ventures: the limits of theories from international business research. Journal of Business Venturing, 9(6), 469-487.

Miller, P., \& Bound, K. (2011). The startup factories. London: NESTA.

Moore, J. F. (1993). Predators and prey: a new ecology of competition. Harvard Business Review, 71(3), 75-83.

Motoyama, Y., \& Knowlton, K. (2016). From resource munificence to ecosystem integration: the case of government sponsorship in St. Louis. Entrepreneurship and Regional Development. doi:10.1080/08985626.2016.1186749.

Myrdal, G. (1957). Economic theory and under-development regions. Gerarld Duckworth.

Nambisan, S., \& Baron, R. A. (2013). Entrepreneurship in innovation ecosystems: entrepreneurs' self-regulatory processes and their implications for new venture success. Entrepreneurship Theory and Practice, 37(5), 1071-1097.

Napier, G., \& Hansen, C. (2011). Ecosystems for young scaleable firms. Cophehagen: FORA Group.

Neck, H. M., Meyer, G. D., Cohen, B., \& Corbett, A. C. (2004). An entrepreneurial system view of new venture creation. Journal of Small Business Management, 42(2), 190-208.

Nightingale, P., Murray, G., Cowling, M., Baden-Fuller, C., Mason, C., Siepel, J., et al. (2009). From funding gaps to thin markets: UK government support for early-stage venture capital. London: Nesta.

Nightingale, P., \& Coad, A. (2014). Muppets and gazelles: Political and methodological biases in entrepreneurship research. Industrial and Corporate Change, 23(1), 113-143.

North, D., Baldock, R., \& Ullah, F. (2013). Funding the growth of UK technology-based small firms since the financial crash: are there breakages in the finance escalator? Venture Capital, 15(3), 237-260.

O'Connor, A. (2013). A conceptual framework for entrepreneurship education policy: meeting government and economic purposes. Journal of Business Venturing, 28, 546-563.

Parker, S. C. (2013). Do serial entrepreneurs run successively better-performing businesses? Journal of Business Venturing, 28(5), 652-666.

Pathak, S., Laplume, A., \& Xavier-Oliveira, E. (2015). Inbound foreign direct investment and domestic entrepreneurial activity. Entrepreneurship \& Regional Development, 27(5-6), 334-356.

Pfeffer, J., \& Salancik, G. R. (2003). The external control of organizations: a resource dependence perspective. Stanford University Press.

Piore, M. J., \& Sabel, C. F. (1984). The second industrial divide: possibilities for prosperity. Basic books.

Porter, M. E. (2000). Location, competition, and economic development: local clusters in a global economy. Economic Development Quarterly, 14(1), 15-34.

Rodríguez-Pose, A., \& Crescenzi, R. (2008). Mountains in a flat world: why proximity still matters for the location of economic activity. Cambridge Journal of Regions, Economy and Society, 1(3), 371-388.

Qian, H., Acs, Z. J., \& Stough, R. R. (2013). Regional systems of entrepreneurship: the nexus of human capital, knowledge and new firm formation. Journal of Economic Geography, 13(4), 559-587.

Quatraro, F., \& Vivarelli, M. (2015). Drivers of entrepreneurship and post-entry performance of newborn firms in developing countries. The World Bank Research Observer, 30((20)), 277-305.

Sarasvathy, S. D. (2001). Causation and effectuation: Toward a theoretical shift from economic inevitability to entrepreneurial contingency. Academy of Management Review, 26(2), 243-263.

Saxenian, A. (1996). Regional advantage. Harvard University Press. 
Schneider, C., \& Veugelers, R. (2010). On young highly innovative companies: why they matter and how (not) to policy support them. Industrial and Corporate Change, 19(4), 9691007.

Schreiber, U., \& Pinelli, M. (2013). The power of three: Together, governments, entrepreneurs and corporations can spur growth across the G20. The EY G20 entrepreneurship barometer 2013. London: EYGM Limited.

Scott, A. J. (2006). Geography and economy. Oxford: Oxford University Press.

Shane, S. (2009). Why encouraging more people to become entrepreneurs is bad public policy. Small Business Economics, 33(2), 141-149.

Smits, R., \& Kuhlmann, S. (2004). The rise of systemic instruments in innovation policy. International Journal of Foresight and Innovation Policy, 1(1-2), 4-32.

Spigel, B. (2015). The relational organization of entrepreneurial ecosystems.Entrepreneurship Theory and Practice. Published online first DOI: 10.1111/etap.12167.

Spilling, O. R. (1996). The entrepreneurial system: on entrepreneurship in the context of a mega-event. Journal of Business Research, 36(1), 91-103.

Stam, E. (2007). Why butterflies don't leave: locational behavior of entrepreneurial firms. Economic Geography, 27-50.

Stam, E. (2015). Entrepreneurial ecosystems and regional policy: a sympathetic critique. European Planning Studies, 23(9), 1759-1769.

Stangler, D., \& Bell-Masterton, J. (2015). Measuring and entrepreneurial ecosystem. Kansas City: Kauffman Foundation.

Storper, M. (1995). The resurgence of regional economies, ten years later the region as a nexus of untraded interdependencies. European Urban and Regional Studies, 2(3), 191221.

Storper, M., \& Venables, A. J. (2004). Buzz: face-to-face contact and the urban economy. Journal of Economic Geography, 4(4), 351-370.

Sullivan, D. M., \& Ford, C. M. (2014). How entrepreneurs use networks to address changing resource requirements during early venture development. Entrepreneurship Theory and Practice, 38(3), 551-574.

Sweeney, G P (1987) Innovation, entrepreneurs and regional development, London; Pinter.

Teece, D. J., Rumelt, R., Dosi, G., \& Winter, S. (1994). Understanding corporate coherence: theory and evidence. Journal of Economic Behavior \& Organization, 23(1), 1-30.

Teece, D. J. (2007). Explicating dynamic capabilities: the nature and microfoundations of (sustainable) enterprise performance. Strategic Management Journal, 28(13), 1319-1350.

Teece, D. J. (2014). The foundations of enterprise performance: dynamic and ordinary capabilities in an (economic) theory of firms. The Academy of Management Perspectives, 28(4), $328-352$.
Van der Panne, G. (2004). Agglomeration externalities: Marshall versus Jacobs. Journal of Evolutionary Economics, 14(5), 593-604.

van der Panne, G., \& Van Beers, C. (2006). On the MarshallJacobs controversy: it takes two to tango. Industrial and Corporate Change, 15(5), 877-890.

Van Stel, A., \& Storey, D. (2004). The link between firm births and job creation: is there a Upas tree effect? Regional Studies, 38(8), 893-909.

Venkataraman, S. (2004). Regional transformation through technological entrepreneurship. Journal of Business Venturing, 19(1), 153-167.

Vivarelli, M. (2004). Are all the potential entrepreneurs so good? Small Business Economics, 23(1), 41-49.

Vivarelli, M. (2013). Is entrepreneurship necessarily good? Microeconomic evidence from developed and developing countries. Industrial and Corporate Change, 22(6), 1453-1495.

Vogel, P. (2013). The employment outlook for youth: building entrepreneurial ecosystems as a way forward. In An essay for the G20 youth Forum 2013. St Petersburg: Russia.

Vos, E., Yeh, A. J. Y., Carter, S., \& Tagg, S. (2007). The happy story of small business financing. Journal of Banking \& Finance, 31(9), 2648-2672.

Walshok, M. L., Furtek, E., Lee, C. W., \& Windham, P. H. (2002). Building regional innovation capacity: the San Diego experience. Industry and Higher Education, 16(1), 27-42.

Warwick, K. (2013). Beyond Industrial Policy: Emerging Issues and New Trends, OECD Science, Technology and Industry Policy Papers, No. 2. Paris: OECD Publishing.

Welter, F. (2011). Contextualizing entrepreneurship - conceptual challenges and ways forward. Entrepreneurship Theory and Practice, 35(1), 165-184.

Welter, F., Baker, T., Audretsch, D. B., \& Gartner, W. B. (2016). Everyday entrepreneurship - a call for entrepreneurship research to embrace entrepreneurial diversity. Entrepreneurship Theory and Practice. doi:10.1111 /etap. 12258.

Wieczorek, A. J., \& Hekkert, M. P. (2012). Systemic instruments for systemic innovation problems: a framework for policy makers and innovation scholars. Science and Public Policy, 39(1), 74-87.

Witt, P. (2004). Entrepreneurs' networks and the success of start-ups. Entrepreneurship and Regional Development, 16(5), 391-412.

WEF. (2014). Entrepreneurial ecosystems and around the globe and early-stage company growth dynamics - an entrepreneurs perspective. Davos: World Economic Forum http://www 3.weforum.org/docs/WEF_II_ EntrepreneurialEcosystemsEarlyStageCompany_ Report_2014.pdf.

Zahra, S. A., \& Nambisan, S. (2011). Entrepreneurship in global innovation ecosystems. AMS review, 1(1), 4-17.

Zhang, J. (2011). The advantage of experienced start-up founders in venture capital acquisition: evidence from serial entrepreneurs. Small Business Economics, 36(2), 187-208. 